\title{
Recent Advancement on Phytochemical Analysis and Pharmacological Value of Linum usitatissimum $L$.
}

\author{
Bhawana Nidhi, Prashant K Dhakad*, Ganesh N. Sharma, Birendra Srivastava \\ School of Pharmaceutical Sciences, Jaipur National University, Jaipur, Rajasthan, India \\ Received December 28, 2019; Revised March 2, 2020; Accepted March 12, 2020
}

Copyright $(2020$ by authors, all rights reserved. Authors agree that this article remains permanently open access under the terms of the Creative Commons Attribution License 4.0 International License

\begin{abstract}
Linum usitatissimum L. (Flaxseed) otherwise called linseed and is developed significantly for seeds all through the world for therapeutic and commercial purposes. It is a yearly herb found in the Linaceae family. The plant of flax contains light blue blooms and capsules of fruits loaded up with little, dark-colored seeds. Flaxseed is utilized all through the world for their fiber content and oil. Flaxseed oil is the most extravagant wellspring of the omega-3 unsaturated fat Linolenic acid with a run of the mill levels of fifty-five percent in the oil. Flaxseed contains numerous bioactive mixes like cyclic peptides, lignans, proteins, cynogenic glycosides and dissolvable and insoluble strands. From the antiquated time, flaxseed has been utilized as an emollient, topical demulcent, and diuretic, especially for animals. Flaxseed cakes have been utilized as cows feed. This plant gives pharmacological uses to human body in serious sicknesses, as in bipolar issue, git obstruction, malignant growth, dyslipidemia, diabetes, platelet aggregation, hypertension, depression, lupus nephritis, Attention deficit hyperactivity disorder, gout, menopausal side effects. The advantages of utilization of entire flaxseed parts, for example, whole oil, mucilage, and protein demonstrate that whole arrangement of constituents present is required to conform to pharmacological action with explicit compound.
\end{abstract}

Keywords Linum usitatissimum L., Flaxseed Oil, Omega-3 Fatty Acid, Pharmacological, Linaceae

\section{Introduction}

Flax seed are utilized all through the world for their oil and fiber content [1]. Flaxseed otherwise called linseed is generally used for the seeds all through the world. Its Latin name Linum usitatissimum L. signifies "extremely valuable". There are two assortments of flaxseed dark colored brown and brilliant gold [2]. Flax seed are developed everywhere throughout the world with most elevated generation in Canada. The plant of flax contains light blue blooms and natural product cases loaded up with little, dark colored seed $[3,4]$. As per survey the normal generation of flaxseed is in excess of 1.8 million tons [5]. This one is the most established developed harvests, keeps on being generally done for oil, fiber and nourishment. All aspects of the flaxseed plant are for the most part used for monetarily, either legitimately or after processing [2]. Ordinarily utilized types of flaxseed for human use are entire flaxseed, flaxseed oil, ground flaxseed and somewhat defatted flaxseed supper [3, 4]. From the antiquated time flaxseed has been utilized as a topical demulcent, emollient and diuretic, especially for creatures. Flaxseed cakes have been utilized as steers feed. Customarily it was utilized for expelling outside material from the eye. For expulsion of outside material a soaked seed was put under the shut eyelid for scarcely any developments to enable the material to cling to the seed. Flaxseed likewise used to treat hacks, cold, blockage, and urinary tract disease $[5,6]$.

Scientific Classification

Kingdom: Plantae

Order: Malpighiales

Family: Linaceae

Genus: Linum

Species: L. usitatissimum

Binomial name: Linum usitatissimum

Synonym: Linum crepitans, Linum humile, Linum indehiscens

\subsection{Botanical Description}

The plant of flax is thin yearly which becomes $0.3-0.9$ $\mathrm{m}$ in tallness. At the highest point of plant it has light green, little, and alternating leaves. The yellow flaxseed is oval and level, around $5 \mathrm{~mm}$ in length including an endosperm and 2 embryos [7]. The incipient organism and cotyledons are covered by a gleaming dark colored 
structure. Oleosomes are found in endosperm and cotyledons within seeds. The most elevated protein present in flaxseed is arginine about 10 to $30 \%$, around 55 to $70 \%$ of absolute arginine is available in cotyledons staying $30 \%$ found in endosperm and seed coat. Flaxseed possesses $20 \%$ of soluble fibres while $9 \%$ of insoluble strands is found in the body [3]. Right off the bat flax was acquainted with North America from Europe and now develops in Canada and north western US. Different individuals from the family Linum are utilized all through the world for oil and fiber content [7].

\section{Phytochemistry}

Flaxseed contain different synthetic constituent like $\alpha$ lipoic acid, linoic acid, cyclic peptides, lignans, protein, cyanogenic glycosides, soluble and insoluble fiber. Soluble fiber made out of D-xylose, L-galactose, L-rhamnose, L-fructose, and characteristic polysaccharides like D-galactose, L-arabinose. Insoluble fiber contains lignin, cellulose, acid cleanser fiber. Secoisolariciresinol diglucoside is found in the seed layer of flaxseed. The flax lignin complex which is separated from flaxseed contains secoisolariciresinol diglucoside, hydroxymethylglutaric acid and cinnamic acid glucoside [7]. As indicated by an investigation accomplished for bioprocessing of useful element of flaxseed, flaxseed contains significant level of phytotoxic mixes which can diminish bioavailability of supplements after utilization like phytic acids, linatine, cynogenic glycosides such as linamarin, lotaustralin, linustatin, neolinustatin, and protease inhibitors.

Phytic acid found in flaxseed meddles with ingestion of minerals like zinc, calcium, iron, copper, and magnesium. Cynogenic glycosides on hydrolysis discharge hydrogen cyanide (respiratory inhibitor which goes to change over into thiocynates which block iodine take-up by thyroid organ and long haul presentation cause iodine-insufficiency issue like cretinism and goitre). So as per this examination these antinutritive mixes are undependable for utilization so they evacuated all these mixes by bioprocessing of flaxseed [9]. Flaxseed lignans are utilized in view of their wide range of organic action and useful wellbeing capacities, like anti-oxidant, hostile to disease and diabetes avoidance. The vast majority of the activity is happen by the impact of secoisolariciresinol diglucoside and its subsidiaries enterodiol and enterolactone which is shaped in mammals by the activity of intestinal microorganisms in human colon [10]. There are basically three substance mixes of flaxseed which is advantageous for counteractive action and treatment of different cardiovascular illnesses alpha lipoic acid, secoisolariciresinol diglucoside, and flaxseed fibres [11]. Lignans which is available in flaxseed is a piece of macromolecules where they are associated by the linker-particle hydroxymethyl glutaric acid. In an examination lignan macromolecules was separated from flaxseed bodies and debased to its monomeric compound by complete saponification and they have found flavanoid herbectin diglucoside with secoisolariciresinol diglucoside, p-coumaric acid glucoside, and ferulic acid glucoside by utilizing Reverse phase-High Performance Liquid Chromatography [12].

Jingjing Fang et al. (2012) examined the fixation energy of secoisolariciresinol diglucoside and its biosynthetic forerunner coniferin in creating flaxseed by utilizing a reversed-phase high-performance liquid chromatography-diode array detection technique. What's more, they have discovered that biosynthesis of coniferin isn't synchronous with that of secoisolariciresinol diglucoside. Thus, the centralizations of secoisolariciresinol diglucoside and coniferin change during flaxseed improvement [10]. Ophelie fliniaux (2014) completed microwave-helped extraction of herbacetin diglucoside from flax seed cakes and its evaluation utilizing a RP-HPLC-UV System, and they have discovered that the enhanced strategy was demonstrated to be fast and dependable regarding exactness, repeatability, strength and precision for the extraction of herbacetin diglucoside, and Comparison with a customary extraction technique exhibited that microwave-assisted extraction is progressively successful and less tedious [12]. Małgorzata Tanska (2017) look at the impact of sinapic and ferulic acids subsidiaries (4-vinylsyringol versus 4-vinylguaiacol) as cell reinforcements of rapeseed, flaxseed, and additional virgin olive oils. It was seen that all the above subordinates might be utilized as cell reinforcements in an intricate grid of normal oils. Vinyl-subsidiary was a particularly powerful cell reinforcement of flaxseed oil, which is poor in characteristic cancer prevention agents, and high in polyunsaturated unsaturated fats [13]. Sue-Siang Teh (2015), completed the impact coordinated examination of cold-pressed hemp, flax and canola seed oils by planar chromatography connected with bioassays and mass spectrometry, and found that cool squeezed oils contained intensifies that apply antimicrobial, antioxidative, estrogenic exercises, acetylcholinesterase inhibitory [14]. Hong Wang (2016) explored the impact of germination on lignan biosynthesis, and cancer prevention agent and antiproliferative exercises in Flaxseed for 10 days, and the outcome shows that germination for 8-10 days prompts ideal lignan creation and potential medical advantages whenever fused into the human eating regimen [15]. R. Marino (2018) contemplated the impacts of entire linseed supplementation and treatment span on unsaturated fat profile and endogenous bioactive mixes of hamburger muscle and saw that a momentary eating regimen control is adequate to improve the nourishing properties of meat, including n-3 poly unsaturated fatty acids and bioactive mixes [16]. Masaki Fujisawa (2008) explored the advancement of carotenoids in flaxseed by 
metabolic designing with presentation of bacterial phytoene synthase quality crtb. Also, they found that motion of phytoene amalgamation from geranyl diphosphate was first advanced by the communicated crtB quality item (CrtB), and afterward phytoene was continuously decayed to the downstream metabolites $\beta$-carotene, lutein and $\alpha$-carotene, as catalyzed by endogenous carotenoid biosynthetic proteins in seeds [17]. Natalia Mikołajczak et al. (2019), examined the effect of the expansion of 4-vinyl-subsidiaries of ferulic and sinapic acids on maintenance of unsaturated fats and terpenoids in cold-pressed flaxseed and rapeseed oils during the acceptance time of oxidation and they have discovered that the utilization of 4-vinylsyringol (4-VS) or 4-vinylquaiacol (4-VQ) expanded the maintenance of flawless sterols and carotenoids and squalene. The 4-VQ expansion additionally restrained the $\alpha$-linolenic acid loss [18]. Zhi-Jian Tan (2015) completed the ionic fluid based ultrasonic-helped extraction of secoisolariciresinol<smiles>C=Cc1cc(OC)c(O)c(OC)c1</smiles>

(a)<smiles>CC/C=C\C/C=C\C/C=C\CCCCCCCC(=O)O</smiles>

(c)<smiles>O=C(O)/C=C/c1ccccc1</smiles>

(d) Figures 2 (a-e) respectively.

(b) diglucoside from flaxseed with further decontamination by a watery two-stage framework, and a few parameters were researched to get the ideal extraction productivity. The mix of ionic liquid-based ultrasonic-assisted extraction and ionic liquid-based aqueous two-phase system makes up a straightforward and successful philosophy for the extraction and cleaning of secoisolariciresinol diglucoside [19]. Li Song (2014), separated the methyl jasmonate glycoside subsidiary, mega stigmane subordinate and $2 \mathrm{C}-28$ steroids with 3-beta, 5-beta-cis-dihydroxyl with 8 known mixes from $70 \%$ ethanol concentrate of linseed and explained the structure by utilizing spectroscopic techniques including, nuclear magnetic resonance, high-resolution electrospray ionisation mass spectrometry, and dimolybdenum tetraacetate actuated CD [20]. The Phytochemistry and various parts of has been described in Figure $1(\mathrm{a}-\mathrm{k})$ and<smiles>C=Cc1ccc(O)c(OC)c1</smiles><smiles>O=CC(O)C(O)C(O)C(O)CO</smiles><smiles>OC1OC[C@@H](O)[C@H](O)[C@@H]1O</smiles>

(e)

(f) 


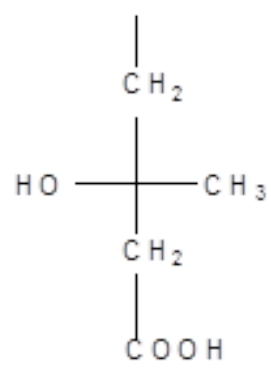

(g)<smiles>O=C(CO)[C@H](O)[C@H](O)[C@H](O)CO</smiles>

(h)

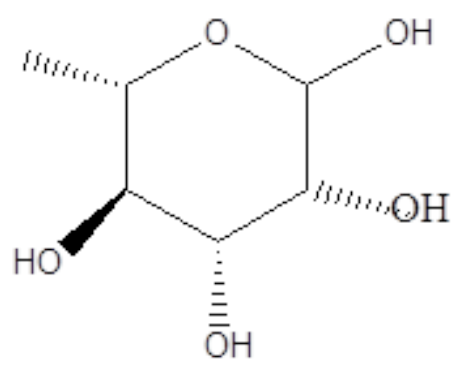

(i)<smiles>COc1cc(C=C(CO[C@H]2O[C@H](CO)[C@@H](O)[C@H](O)[C@H]2O)[C@H](CO[C@H]2O[C@H](CO)C[C@@H](O)[C@H]2O)Cc2ccc(O)c(OC)c2)ccc1O</smiles>

(j)<smiles>CCCCCC=CCC=CCCCCCCCC(=O)O</smiles>

(k)

Figure 1(a-k). (a)=4-vinylsyringol, $(\mathrm{b})=4$-vinylguaiacol, $(\mathrm{c})=$ Alpha-linolenic acid, $(\mathrm{d})=$ Cinnamic acid, $(\mathrm{e})=\mathrm{D}$-galactose, $(\mathrm{f})=\mathrm{D}-\mathrm{xylose}, \quad(\mathrm{g})=$ Hydroxymethyl glutaric acid, $(\mathrm{h})=\mathrm{L}$-fructose,$(\mathrm{i})=\mathrm{L}$-rhamnos, $(\mathrm{j})=$ Secoisolarciresinol diglucoside, $(\mathrm{k})=$ Linoleic acid 


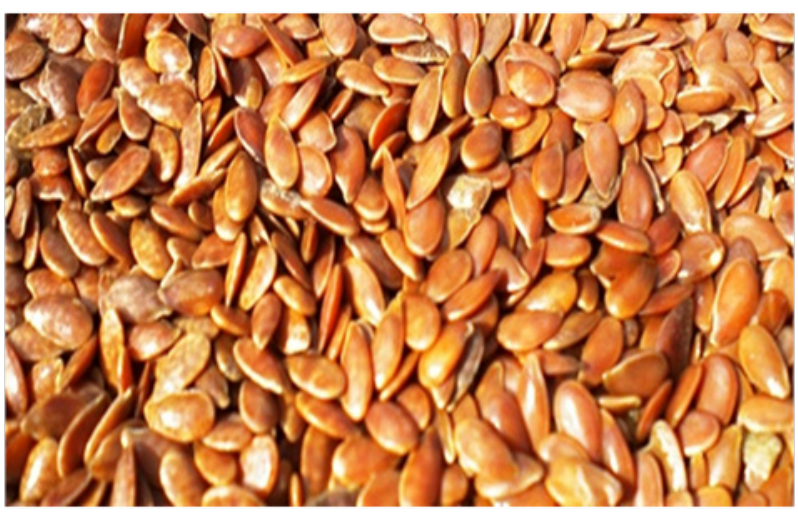

(a)

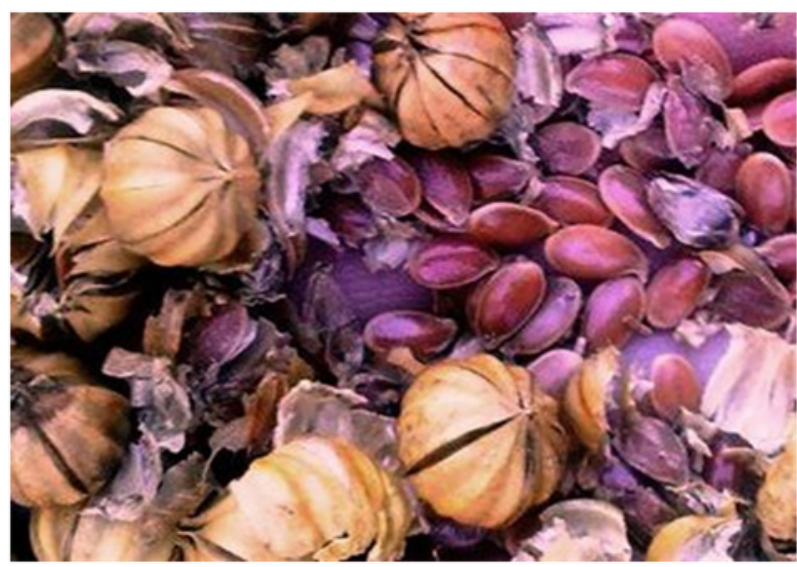

(c)

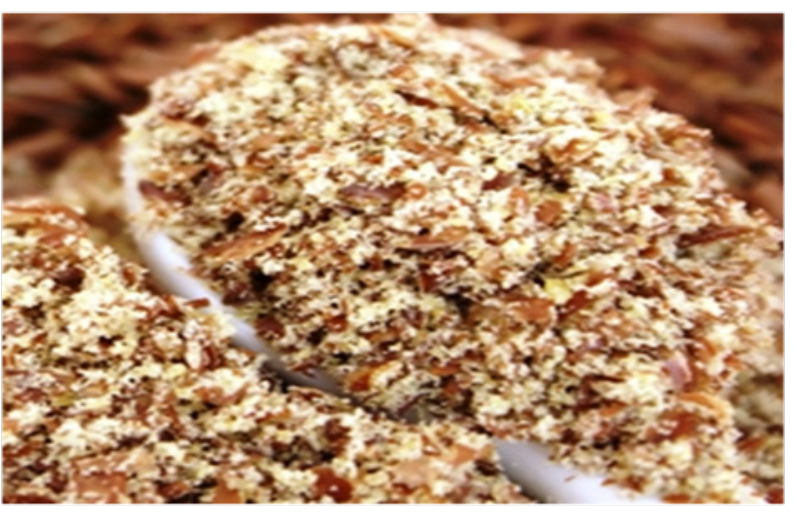

(b)

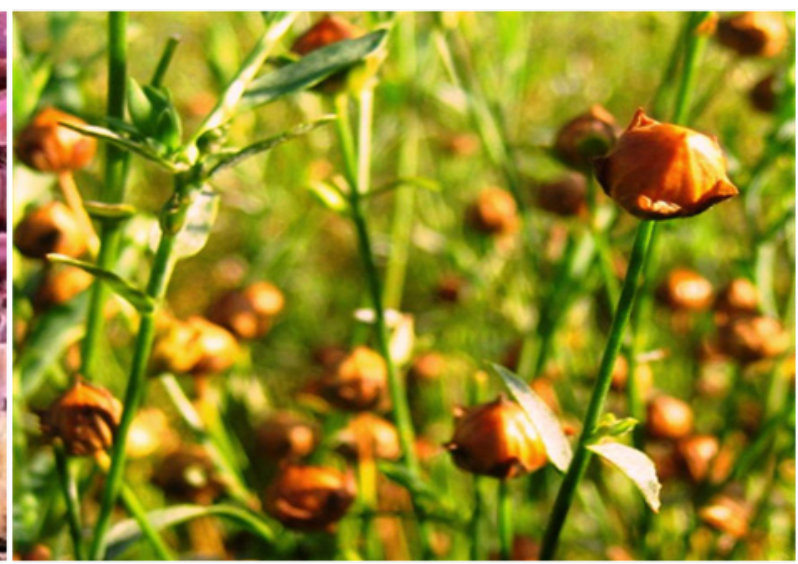

(d)

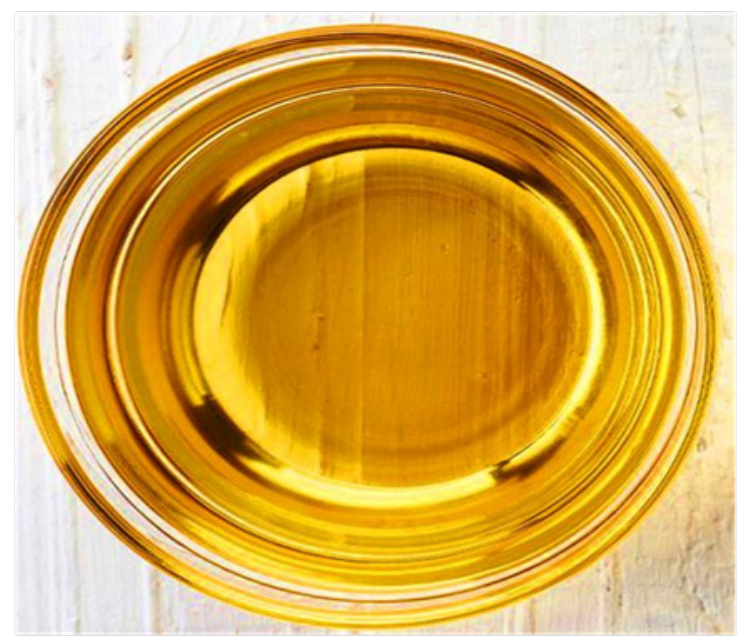

(e)

Figure 2 (a-e). (a) Flax seeds (b) Flax seed powder (c) Flax seed pods and bursting seeds (d) Flax seed stem, leaves and buds (e) Flax seed oil

\section{Pharmacological Activities}

There are different types of flaxseeds accessible for human utilization like ground entire seed, partially defatted flaxseed meal, flaxseed oil, ground whole seed, whole seed, bluntly defatted flaxseed meal, flaxseed alcohol extract, flaxseed husk, flaxseed oleosomes. These flaxseed items show their fruitful impacts on human body [1]. A wide range of scientific studies on flaxseed and its pharmacological actions is demonstrated in Table 1. 
Table 1. Some pharmacological activities of flaxseed plant along with suitable outcomes

\begin{tabular}{|c|c|c|c|c|}
\hline S.No. & $\begin{array}{c}\text { Pharmacological } \\
\text { uses }\end{array}$ & & Research outcomes & References \\
\hline 1 & Antidepressant & $\begin{array}{l}\text { a) } \\
\text { b) }\end{array}$ & $\begin{array}{l}\text { Secoisolarciresinol diglucoside possess this effect. } \\
\text { Flaxseed intake during pregnancy prevents depressive symptoms and promotes } \\
\text { neuroprotective effect. }\end{array}$ & {$[21,22]$} \\
\hline 2 & Anti-platelet & $\begin{array}{l}\text { a) } \\
\text { b) }\end{array}$ & $\begin{array}{l}\text { Secoisolarciresinol diglucoside act as an antagonist of platelet-activating factor. } \\
\text { Epidemiological data and theoretical mechanism of action indicate the potential } \\
\text { platelet inhibitory effects of ALA; human studies have not shown anti-platelet } \\
\text { action. }\end{array}$ & $\begin{array}{c}{[22,23,24]} \\
{[25,26]}\end{array}$ \\
\hline 3 & Appetite suppression & a) & Dietary fiber of flaxseed may help to a sensation of satiety and fullness. & [27] \\
\hline 4 & $\begin{array}{l}\text { Attention Deficit } \\
\text { Hyperactivity } \\
\text { Disorder (ADHD) }\end{array}$ & a) & $\begin{array}{l}\text { Flaxseed oil improves the symptoms of ADHD children in a pilot study because } \\
\text { ADHD is commonly associated with low blood omega- } 3 \text { fatty acid levels. }\end{array}$ & {$[28,29]$} \\
\hline 6 & Bipolar disorder & a) & $\begin{array}{l}\text { A meta-analysis shows evidence that adjunctive use of omega-3 improve } \\
\text { bipolar depression but it does not support its use in mania. } \\
\text { Clinical study conducted on paediatrics to treat bipolar depression or mania, } \\
\text { effects of flaxseed supplementation was not differing from those of placebo. }\end{array}$ & $\begin{array}{l}{[30]} \\
{[31]}\end{array}$ \\
\hline 7 & Constipation & a) & $\begin{array}{l}\text { In } 50 \text { adult hemodialysis patients with constipation were evaluated by giving } \\
\text { flaxseed oil in comparison to mineral oil and flaxseed oil improve the } \\
\text { frequency and consistency of stools. }\end{array}$ & [32] \\
\hline 8 & Dermatology & a) & $\begin{array}{l}\text { A study shows that flaxseed oil with oil supplementation may improve skin } \\
\text { hydration and reduce sensitivity. }\end{array}$ & {$[33,34]$} \\
\hline 9 & Dyslipidemia & $\begin{array}{l}\text { c) } \\
\text { d) } \\
\text { e) }\end{array}$ & $\begin{array}{l}\text { Various studies have been conducted to investigate role of flaxseed for } \\
\text { atherosclerotic lesions reduction, reduce platelet aggregation, reduce } \\
\text { low-density lipoprotein-cholesterol, and QT interval prolongation. } \\
\text { A meta-analysis and reviews on the effect of flaxseed on serum cholesterol } \\
\text { have been published. } \\
\text { A meta-analysis of } 28 \text { clinical trials up to } 2008 \text { found that whole flaxseed and } \\
\text { lignan alone modestly reduced total cholesterol and LDL but no changes in } \\
\text { HDL-C or triglycerides were found. } \\
\text { Some other clinical studies done after Meta-analysis which found flaxseed } \\
\text { reduce LDL levels. } \\
\text { Flaxseed has no effect on markers of inflammation. }\end{array}$ & $\begin{array}{c}{[21,22,35,36]} \\
{[21,25,22,35,} \\
36,37] \\
{[36]} \\
{[38,39,40,41]} \\
{[37,38,39,42,} \\
43]\end{array}$ \\
\hline 10 & Cancer & $\begin{array}{l}\text { c) } \\
\text { d) } \\
\text { e) } \\
\text { f) }\end{array}$ & $\begin{array}{l}\text { Phytoestrogens and ALA present in flaxseed have cancer protective effects but } \\
\text { its mechanism of action is not completely defined. } \\
\text { Flaxseed and lignan gave positive report in animal studies on colon cancer, } \\
\text { melanoma, and mammary gland cancer. But flaxseed oil did not show any } \\
\text { protective effect in colon cancer. } \\
\text { In clinical trials there is lack of specific use of flaxseed in breast cancer and its } \\
\text { use in because of ALA and omega-3 in breast cancer is debated. } \\
\text { In a study in newly diagnosed postmenopausal breast cancer patients, dietry } \\
\text { flaxseed showed positive effects. } \\
\text { ALA increase risk for prostate cancer suggested by previous studies. } \\
\text { Flaxseed lignans can prevent symptoms associated with benign prostatic } \\
\text { hyperplasia. }\end{array}$ & $\begin{array}{c}{[44,45]} \\
{[21,22,37,46]} \\
{[26,47]} \\
{[48]} \\
{[49,50,51]} \\
{[52]}\end{array}$ \\
\hline 11 & Diabetes & a) & $\begin{array}{l}\text { According to some animal studies flaxseed and its fibre can affect insulin } \\
\text { secretion and its mechanism of action. } \\
\text { In a clinical study flax fibre and lignan secoisolarciresinol diglucoside } \\
\text { improved the glycemic control in healthy volunteers, postmenopausal women } \\
\text { and hyperlipidemic men. } \\
\text { Ground flaxseed and secoisolarciresinol diglucoside reduced insulin resistance } \\
\text { and improve lipid profiles in patients with type } 2 \text { diabetes and in glucose } \\
\text { tolerant obese people. } \\
\text { In a randomized control trial flaxseed supplementation improved glucose, } \\
\text { insulin and insulin sensitivity in prediabetic overweight or obese men and } \\
\text { postmenopausal women. }\end{array}$ & $\begin{array}{c}{[25,53]} \\
{[54,55,56,57]} \\
{[22,58,59,60]} \\
{[61]}\end{array}$ \\
\hline
\end{tabular}


Table 1 Continued

\begin{tabular}{|c|c|c|c|c|}
\hline 12 & Gout & a) & $\begin{array}{l}\text { Guidelines on the management of gout given by American college of } \\
\text { rheumatology suggested that flaxseed was not suitable for acute attack of gout. }\end{array}$ & {$[62]$} \\
\hline 13 & Hypertension & b) & $\begin{array}{l}\text { In a clinical trial effects of milled flaxseed evaluated for } 6 \text { months on blood } \\
\text { pressure and flaxseed lower the b.p. }\end{array}$ & {$[63]$} \\
\hline 14 & Lupus nephritis & $\begin{array}{l}\text { a) } \\
\text { b) }\end{array}$ & $\begin{array}{l}\text { Flaxseed has potential in helping patients who develop lupus nephritis. } \\
\text { Some mouse models of lupus shows that diet supplemented with } 15 \% \text { flaxseed } \\
\text { delayed the onset of proteinuria and reduced overall mortality. }\end{array}$ & $\begin{array}{l}{[64]} \\
{[24]}\end{array}$ \\
\hline 15 & $\begin{array}{l}\text { Menopausal } \\
\text { symptoms }\end{array}$ & a) & $\begin{array}{l}\text { Flaxseed contains photo estrogenic content which may benefit women } \\
\text { suffering from menopausal symptoms. } \\
\text { The society of obstetricians and gynaecologist of Canada revised clinical } \\
\text { practice guidelines on managing menopause (2014) do not recommend } \\
\text { flaxseed for menopausal symptoms because of lack of evidence to support } \\
\text { clinical benefit. }\end{array}$ & {$[65]$} \\
\hline
\end{tabular}

\section{Conclusions}

Flaxseed is perhaps the most extravagant wellspring of the fundamental unsaturated fat $\alpha$-linolenic acid and lignan secoisolariciresinol diglucoside. Likewise, new segments of flax have as of late been recognized that additionally show natural impacts. SDG reestablishes vascular capacity by expanding neovascularization and in this manner improves cardiovascular capacity. It likewise has incredible cancer prevention agent action. Flax oil has additionally had antihypertensive potential. Flaxseed coat materials are known as rich wellspring of polysaccharide mucilage. Flaxseed has numerous medical advantages just as rich of supplements. Truth be told the substance like fiber, proteins, amino acids, nutrient $\mathrm{E}$ and lignans present in flaxseed fulfil fundamental needs in the human eating routine. Flaxseed is a phenomenal plant nourishment competitor that addresses the issues of the 21 st century buyer as far as being wealthy in supplements just as bioactive and useful fixings. Flaxseed demonstrated different pharmacological activities and the modernized methods like micro fluidization, high power ultrasound, nanoencapsulation and spray granulation will clear route for new ways to deal with the preparing, adjustment and usage of flaxseed oil. Further, advancement of diets of the creatures with flax/flaxseed oil for generation of omega-3 enhanced eggs, meat, milk, and other creature starting point items could be another methodology in using flaxseeds.

\section{Acknowledgements}

We are very grateful to Prof. (Dr.) Soumana Datta, Department of Botany, University of Rajasthan, for providing detailed information and suggestions about the present work done on Linum usitatissimum $L$.

\section{REFERENCES}

[1] Youn YS, Bo G, Paul GA, Yong W, Martin JT. Flaxseed (Linum usitatissimum L.) bioactive compounds and peptide nomenclature: A review. Food science and Technology. 2014; 38: 5-20.

[2] Chishty S, Bissu M. Health Benefits and Nutritional Value of Flaxseed-a Review. Indian Journal of Applied Research. 2016; 6(1): 243-245.

[3] "The Plant List: A Working List of All Plant Species". Retrieved 2 October 2014.

[4] Singh KK, Mridula D, Rehal J, Barnwal P. Flaxseed: A potential source of food, feed and fiber. Crit Rev Food Sci Nutr. 2011;51(3):210-222.

[5] Blumenthal M, Goldberg A, Brinckmann J. eds. Herbal Medicine, Expanded Commission E Monographs. Newton, MA: Integrative Medicine Communications; 2000.

[6] Evans WC. Trease and Evans' Pharmacognosy. 13th ed. London: Balliere Tindall; 1989.

[7] Mihir P, Thomas N, Grant N. Pierce. Flaxseed: Its Bioactive Components and their Cardiovascular Benefits. Am J Physiol Heart Circ Physiol. 2018; 314: 146-159.

[8] Linum usitatissimum. USDA, NRCS. 2007. The PLANTS Database (http://plants.usda.gov, December 11, 2012). National Plant Data Team, Greensboro, NC 27401-4901 USA.

[9] Christian KOD, Jordan TT , Caleb A, Sharadwata P, Dominic A. Bioprocessing of Functional Ingredients from Flaxseed. Molecules. 2018; 23(10): 2444.

[10] Jingjing F, Aina R, Christian P, Evangelos T, Sullivan R, Christophe H, Eric G, Ophélie F, Albrecht R, Francois M. Concentration Kinetics of Secoisolariciresinol Diglucoside and its Biosynthetic Precursor Coniferin in Developing Flaxseed, Phytochemical Analysis. 2012; 24: 41-46. 
[11] Mihir P, Grant NP. Dietary flaxseed: what we know and don't know about its effects on cardiovascular disease. Can. J. Physiol. Pharmacol. 2019; 97: 75-81.

[12] Karin S, Jean-Paul V, Rene V, Willemiek HM, Alphons GJV, Harry G. The flavonoid herbacetin diglucoside as a constituent of the lignan macromolecule from flaxseed hulls. Phytochemistry. 2007; 68:1227-1235.

[13] Tańska M, Mikołajczak N, Konopka I. Comparison of the effect of sinapic and ferulic acids derivatives (4-vinylsyringol vs. 4-vinylguaiacol) as antioxidants of rapeseed, flaxseed, and extra virgin olive oils. Food Chemistry. 2018; 240:679-685.

[14] Teh SS, Morlock GE. Effect-directed analysis of cold-pressed hemp, flax and canola seed oils by planar chromatography linked with (bio)assays and mass spectrometry. Food Chem. 2015; 15: (187), 460-468.

[15] Wang H, Wang J, Guo X, Brennan CS, Li T, Fu X, Chen G, Liu RH. Effect of germination on lignan biosynthesis, and antioxidant and antiproliferative activities in flaxseed (Linum usitatissimum L.). Food Chem. 2016; 15(205): 170-177.

[16] Marino R, Della Malva A, Caroprese M, de Palo P, Santillo A, Sevi A, Albenzio M. Effects of whole linseed supplementation and treatment duration on fatty acid profile and endogenous bioactive compounds of beef muscle. Animal. 2019; 13(2): 444-452.

[17] Fujisawa M, Watanabe M, Choi SK, Teramoto M, Ohyama K, Misawa N. Enrichment of carotenoids in flaxseed (Linum usitatissimum) by metabolic engineering with introduction of bacterial phytoene synthase gene crtB. J Biosci Bioeng. 2008; 105(6): 636-641.

[18] Fujisawa M, Watanabe M, Choi SK, Teramoto M, Ohyama $\mathrm{K}$, Misawa N. Enrichment of carotenoids in flaxseed (Linum usitatissimum) by metabolic engineering with introduction of bacterial phytoene synthase gene crtB. J Biosci Bioeng. 2008; 105(6): 636-641.

[19] Tan ZJ, Wang CY, Yang ZZ, Yi YJ, Wang HY, Zhou WL, Li FF. Ionic Liquid-Based Ultrasonic-Assisted Extraction of Secoisolariciresinol Diglucoside from Flaxseed (Linum usitatissimum L.) with Further Purification by an Aqueous Two-Phase System. Molecules. 2015; 20(10): 17929-17943.

[20] Song L, Wang XF, Wu Y, He WY, Yao CS, Shi JG. Chemical constituents from the linseed meal. Fitoterapia. 2014; 97:15-22.

[21] Basch E, Bent S, Collins J, et al. Flaxseed and flaxseed oil (Linum usitatissimum): A review by the Natural Standards Collaboration. J Soc Integr Oncol. 2007; 5(3): 92-105.

[22] Adolphe JL, Whiting SJ, Juurlink BH, Thorpe LU, Alcorn J. Health effects with consumption of the flax lignan secoisolariciresinol diglucoside. Br J Nutr. 2010; 103(7): 929-938.

[23] Ogborn MR, Nitschmann E, Weiler H, Leswick D, Bankovic-Calic N. Flaxseed ameliorates interstitial nephritis in rat polycystic kidney disease. Kidney Int. 1999; 55(2): 417-423.

[24] Hall AV, Parbtani A, Clark WF, et al. Abrogation of
MRL/lpr lupus nephritis by dietary flaxseed. Am J Kidney Dis. 1993 ; 22(2): 326-332.

[25] Bloedon LT, Szapary PO. Flaxseed and cardiovascular risk. Nutr Rev. 2004; 62(1): 18-27.

[26] Mozaffarian D. Does alpha-linolenic acid intake reduce the risk of coronary heart disease? A review of the evidence. Altern Ther Health Med. 2005; 11(3): 24-30.

[27] Ibrügger S, Kristensen M, Mikkelsen MS, Astrup A. Flaxseed dietary fiber supplements for suppression of appetite and food intake. Appetite. 2012; 2: 490-495.

[28] Young GS, Conquer JA, Thomas R. Effect of randomized supplementation with high dose olive, flax or fish oil on serum phospholipid fatty acid levels in adults with attention deficit hyperactivity disorder. Reprod Nutr Dev. 2005; 45(5): 549-558.

[29] Joshi K, Lad S, Kale M, et al. Supplementation with flax oil and vitamin $\mathrm{C}$ improves the outcome of attention deficit hyperactivity disorder (ADHD). Prostaglandins Leukot Essent Fatty Acids. 2006; 74(1): 17-21.

[30] Sarris J, Mischoulon D, Schweitzer I. Omega-3 for bipolar disorder: Meta-analyses of use in mania and bipolar depression. J Clin Psychiatry. 2012; 73(1): 81-86.

[31] Gracious BL, Chirieac MC, Costescu S, Finucane TL, Youngstrom EA, Hibbeln JR. Randomized, placebo-controlled trial of flax oil in pediatric bipolar disorder. Bipolar Disord. 2010; 12(2): 142-154.

[32] Ramos CI, Andrade de Lima AF, Grilli DG, Cuppari L. The short-term effects of olive oil and flaxseed oil for the treatment of constipation in hemodialysis patients. J Ren Nutr. 2015; 25(1): 50-56.

[33] Neukam K, De Spirt S, Stahl W, Bejot M, Maurette JM, Tronnier H, Heinrich U. Supplementation of flaxseed oil diminishes skin sensitivity and improves skin barrier function and condition. Skin Pharmacol Physiol. 2011; 24(2): $67-74$

[34] The De Spirt S, Stahl W, Tronnier H, et al. Intervention with flaxseed and borage oil supplements modulates skin condition in women. Br J Nutr. 2009; 101(3): 440-445.

[35] Rodriguez-Leyva D, Dupasquier CM, McCullough R, Pierce GN. Cardiovascular effects of flaxseed and its omega-3 fatty acid, alpha-linolenic acid. Can J Cardiol. 2010; 26(9): 489-496.

[36] Pan A, Yu D, Demark-Wahnefried W, Franco OH, Lin X. Meta-analysis of the effects of flaxseed interventions on blood lipids. Am J Clin Nutr. 2009; 90(2): 288-297.

[37] Prasad K. Flaxseed and cardiovascular health. J Cardiovasc Pharmacol. 2009; 54(5): 369-377.

[38] Dewell A, Marvasti FF, Harris WS, Tsao P, Gardner CD. Low- and high-dose plant and marine (n-3) fatty acids do not affect plasma inflammatory markers in adults with metabolic syndrome. J Nutr. 2011; 141(12): 2166-2171.

[39] Faintuch J, Bortolotto LA, Marques PC, Faintuch JJ, Franca JI, Cecconello I. Systemic inflammation and carotid diameter in obese patients: Pilot comparative study with flaxseed powder and cassava powder. Nutr Hosp. 2011; 26(1): 208-213. 
[40] Gillingham LG, Gustafson JA, Han SY, Jassal DS, Jones PJ. High-oleic rapeseed (canola) and flaxseed oils modulate serum lipids and inflammatory biomarkers in hypercholesterolaemic subjects. Br J Nutr. 2011; 105(3): 417-427.

[41] Fukumitsu S, Aida K, Shimizu H, Toyoda K. Flaxseed lignan lowers blood cholesterol and decreases liver disease risk factors in moderately hypercholesterolemic men. Nutr Res. 2010; 30(7): 441-446.

[42] Pan A, Demark-Wahnefried W, Ye X, et al. Effects of a flaxseed-derived lignan supplement on C-reactive protein, IL-6 and retinol-binding protein 4 in type 2 diabetic patients. Br J Nutr. 2009; 101(8): 1145-1149.

[43] Kontogianni MD, Vlassopoulos A, Gatzieva A, Farmaki AE, Katsiougiannis S, Panagiotakos DB, Kalogeropoulos N, Skopouli FN. Flaxseed oil does not affect inflammatory markers and lipid profile compared to olive oil, in young, healthy, normal weight adults. Metabolism. 2013;62(5):686-693.

[44] Hall C III, Tulbek MC, XU Y. Flaxseed. Adv Food Nutr Res. 2006; 51: 1-97.

[45] Wang L, Chen J, Thompson LU. The inhibitory effect of flaxseed on the growth and metastasis of estrogen receptor negative breast cancer xenografts is attributed to both its lignan and oil component. Int J Cancer. 2005; 116(5): 793-798.

[46] Bommareddy A, Arasada BL, Mathees DP, Dwivedi C. Chemoprotective effects of dietary flaxseed on colon tumor development. Nutr Cancer. 2006; 54(2): 216-222.

[47] Saadatian-Elahi M, Norat $T$, Goudable J, Riboli E. Biomarkers of dietary fatty acid intake and the risk of breast cancer: a meta-analysis. Int J Cancer. 2004; 111(4): 584-591.

[48] Thompson LU, Chen JM, Li T, Strasser-Weippl K, Goss PE. Dietary flaxseed alters tumor biological markers in postmenopausal breast cancer. Clin Cancer Res. 2005; 11(10): 3828-3835.

[49] Flaxseed slows prostate tumor growth. Clin Advis. 2007; 10(8): 12.

[50] Demark-Wahnefried W, Price DT, Polascik TJ, et al. Pilot study of dietary fat restriction and flaxseed supplementation in men with prostate cancer before surgery: exploring the effects on hormonal levels, prostate-specific antigen, and histopathologic features. Urology. 2001; 58(1): 47-52.

[51] Demark-Wahnefried W, Robertson CN, Walther PJ, Polascik TJ, Paulson DF, Vollmer RT. Pilot study to explore effects of low-fat, flaxseed-supplemented diet on proliferation of benign prostatic epithelium and prostate-specific antigen. Urology. 2004; 63(5): 900-904.

[52] Zhang W, Wang X, Liu Y, et al. Effects of dietary flaxseed lignan extract on symptoms of benign prostatic hyperplasia. J Med Food. 2008; 11(2): 207-214.

[53] Kaul N, Kreml R, Austria JA, et al. A comparison of fish oil, flaxseed oil and hempseed oil supplementation on selected parameters of cardiovascular health in healthy volunteers. J Am Coll Nutr. 2008; 27(1): 51-58.
[54] Dahl WJ, Lockert EA, Cammer AL, Whiting SJ. Effects of flax fiber on laxation and glycemic response in healthy volunteers. J Med Food. 2005; 8(4): 508-511.

[55] Lemay A, Dodin S, Kadri N, Jacques H, Forest JC. Flaxseed dietary supplement versus hormone replacement therapy in hypercholesterolemic menopausal women. Obstet Gynecol. 2002; 100(3): 495-504.

[56] Bloedon LT, Balikai S, Chittams J, et al. Flaxseed and cardiovascular risk factors: results from a double blind randomized, controlled clinical trial. J Am Coll Nutr. 2008; 27(1): 65-74.

[57] Zhang W, Wang X, Liu Y, et al. Dietary flaxseed lignan extract lowers plasma cholesterol and glucose concentrations in hypercholesterolemic subjects. Br J Nutr. 2008; 99(6): 1301-1309.

[58] Barre DE, Mizier-Barre KA, Griscti O, Hafez K. High dose flaxseed oil supplementation may affect fasting blood serum glucose management in human type 2 diabetics. J Oleo Sci. 2008; 57(5): 269-273.

[59] Mani UV, Mani I, Biswas M, Kumar SN. An open-label study on the effect of flax seed powder (linum usitatissimum) supplementation in the management of diabetes mellitus. J Diet Suppl. 2011; 8(3): 257-265.

[60] Rhee Y, Brunt A. Flaxseed supplementation improved insulin resistance in obese glucose intolerant people: A randomized crossover design. Nutr J. 2011; 10: 44.

[61] Hutchins AM, Brown BD, Cunnane SC, Domitrovich SG, Adams ER, Bobowiec CE. Daily flaxseed consumption improves glycemic control in obese men and women with pre-diabetes: a randomized study. Nutr Res 2013; 33(5): 367-375.

[62] Khanna D, Khanna PP, Fitzgerald JD, et al; American College of Rheumatology. 2012 American College of Rheumatology guidelines for management of gout. Part 2: therapy and anti-inflammatory prophylaxis of acute gouty arthritis. Arthritis Care Res (Hoboken). 2012; 64(10): 1447-1461.

[63] Rodriguez-Leyva D, Weighell W, Edel AL, et al. Potent antihypertensive action of dietary flaxseed in hypertensive patients. Hypertension. 2013; 62(6): 1081-1089.

[64] Yarnell E, Abascal K. Lupus erythematosus and herbal medicine. Altern Complement Ther. 2008; 14(1): 9-12.

[65] Dodin S, Lemay A, Jacques H, Légaré F, Forest JC, Mâsse B. The effects of flaxseed dietary supplement on lipid profile, bone mineral density, and symptoms in menopausal women: a randomized, double-blind, wheat germ placebo-controlled clinical trial. J Clin Endocrinol Metab. 2005; 90(3): 1390-1397.

[66] Reid R, Abramson BL, Blake J, et al. Menopause and Osteoporosis Working Group. Society of Obstetricians and Gynaecologists of Canada. Managing Menopause. J Obstet Gynaecol Can. 2014; 36(9): 830-838. 